\title{
Justice on the Ground: Can International Criminal Courts Strengthen Domestic Rule of Law in Post-Conflict Societies?
}

Jane E. Stromseth

Georgetown University Law Center, stromset@law.georgetown.edu

Copyright @ 2009 Cambridge University Press; http://journals.cambridge.org/action/ displayJournal?jid=ROL

This paper can be downloaded free of charge from:

https://scholarship.law.georgetown.edu/facpub/593

1 Hague J. on Rule L. 87-97 (2009)

This open-access article is brought to you by the Georgetown Law Library. Posted with permission of the author. Follow this and additional works at: https://scholarship.law.georgetown.edu/facpub

Part of the Criminal Law Commons, and the International Law Commons 


\title{
Justice on the Ground: \\ Can International Criminal Courts Strengthen \\ Domestic Rule of Law in Post-Conflict Societies?
}

\author{
Jane Stromseth*
}

\begin{abstract}
The author examines how developments in international criminal law - including creation of the International Criminal Court and various hybrid tribunals - can have an impact on rule-of-law building efforts in post-conflict societies. Although trials of atrocity perpetrators primarily and appropriately focus on fairly trying the accused individuals, these processes also have a wider impact on public perceptions of justice and potentially can influence a society's ability to embrace rule of law norms. The quality of outreach and capacity-building accompanying these trials may well have a decisive effect on whether these proceedings, on balance, strengthen or undermine public confidence in justice and justice institutions in societies recovering from atrocities. This piece stresses the need to supplement international and hybrid criminal trials with more meaningful outreach to the affected populations, and with more systematic domestic capacity-building and empowerment aimed at both formal justice systems and civil society.
\end{abstract}

\section{INTRODUCTION}

We stand at a decisive crossroads in international criminal law. The international and hybrid criminal courts created over the last fifteen years have produced dramatic developments internationally. These tribunals have indicted and tried a number of high-level political and military figures - including former Heads of Statefor egregious crimes, eroding the prospect of impunity for such offenses. These trials have set some groundbreaking legal precedents and have played an educational role in focusing world attention on fundamental rules of international law prohibiting genocide, crimes against humanity, and war crimes. In bringing individual perpetrators to justice, these proceedings have established an official record of the horrendous crimes committed and the criminal responsibilities of those involved. Despite limitations and challenges, the work of these courts is changing the landscape of international justice.

* Professor of Law, Georgetown University Law Center.

$H$ ague ournal on the $R$ ule of $L$ aw, 1:87-97, 2009

(c) 2009 T.M.C.A SSE R PRE SS and C ontributors

doi:10.1017/S1876404509000876 
Far less clear, however, is the impact of these courts on the ground in the societies that endured the atrocities. Are the criminal trials before these tribunals influencing public perceptions of - and confidence in - fair justice in the countries that survived the atrocities? Are international criminal courts - and the "hybrid' tribunals that combine national and international judges and lawyers contributing in any enduring way to building domestic capacity for justice and the rule of law? Notwithstanding the considerable resources and expertise devoted to these courts over the years, we still know surprisingly little about their tangible domestic effects. Thus a crucial challenge in the years ahead will be to better understand the practical impact of international and hybrid criminal tribunals and to develop better strategies to strengthen their contribution to justice on the ground in the societies most directly affected. That is the crossroads we face today: to build stronger links between the work of international and hybrid criminal courts and improvements in domestic rule of law. How we can move in this direction is the focus of this essay.

\section{The Purposes and Challenges of International Criminal Courts}

After bitter conflicts marked by atrocities, questions about how best to face the past - and what forms of accountability and redress to pursue - are often complex and difficult. Different groups and individuals may disagree quite strongly over how hard to press for post-conflict justice, particularly in the face of limited resources, weak domestic justice systems, and fragile peace settlements. Yet, despite these challenges, the trend of the past two decades is clear: criminal prosecution of at least some atrocity perpetrators increasingly has become a key part of post-conflict transitions, particularly after conflicts involving large-scale violence against civilians.

When international or hybrid criminal tribunals prosecute atrocity crimes, they must, of course, focus on their core purpose of bringing individual perpetrators to justice in fair and impartial proceedings. These complex and important trials inevitably require substantial time, financial support, dedication and expertise. Yet modest efforts to enhance their domestic rule of law impact (for example, through early and well-planned outreach to local populations) can potentially make a real difference in building public understanding and confidence that the law can be fair. After all, the people on the ground endured the atrocities and providing meaningful justice to them should surely be an important factor in how we evaluate the contribution of international criminal justice. Otherwise, international and hybrid criminal trials may simply be a 'spaceship' phenomenon: they arrive, do their business, and take off, leaving a befuddled domestic population scratching their heads and wondering what, if anything, this had to do with the dire realities on the 
ground - realities that all too often include desperately under-resourced national judiciaries; limited public awareness or dissemination of laws; a dearth of capable judges, police, prosecutors, or defense attorneys; abysmal prisons; inadequate governmental accountability or transparency; and limited public access to justice in rural areas, just to name a few recurring problems. ${ }^{1}$

International and hybrid criminal courts must do more in the years ahead to contribute to strengthening justice and the rule of law on the ground. Such capacity-building is important because, in the long-term, domestic justice systems that are capable of delivering reasonably fair justice and that enjoy public confidence are crucial to preventing future atrocities and to building a stable rule of law. Indeed, the ultimate impact of international and hybrid courts will be uncertain if their work is completely disconnected from the challenges of strengthening the rule of law domestically in post-conflict societies. Furthermore, if these tribunals fail to address public concerns about their work and simply ignore local perceptions about justice, they may undermine public confidence in fair justice, reinforcing cynicism and despair, rather than helping to build public trust in justice and the rule of law.

Although it will not be easy, international and hybrid criminal courts have real potential to contribute more significantly to justice on the ground in societies recovering from atrocities. Hybrid tribunals in the affected country, in particular, may have some built-in advantages over international courts in contributing to domestic capacity - by virtue of both their location and the direct participation of national judges, prosecutors, defense counsel, investigators, administrators and other staff in their work. But realizing the potential benefits of an in-country hybrid does not happen automatically; it requires astute planning, resources, and sensitivity to the many practical and political challenges that can arise when a tribunal locates directly in the country most affected by the atrocities.

The International Criminal Court's arrival has added an important new actor capable of influencing and prodding domestic justice systems to improve their capacity to investigate and prosecute atrocity crimes - capacity that could have spill-over effects in domestic justice systems more broadly. Yet here too challenges and questions remain. Whether the ICC will be prepared to take a more proactive role in providing - or encouraging others to provide - international assistance to domestic atrocity trials is not yet clear. But even independent of the ICC itself, new, more flexible and informal hybrid arrangements - in which transnational networks provide assistance directly to domesticjustice institutions prosecuting atrocity crimes - may become more significant in the future. The very existence of the

\footnotetext{
${ }^{1}$ For a discussion of the challenges of post-conflict justice system reform, see Jane Stromseth, et al., C an M ight make Rights? Building the R ule of $L$ aw afterM ilitary Interventions, 2006, pp. 178-248.
} 
ICC and its statute, in short, may provide a spur to domestic proceedings assisted by transnational networks. And scholars are producing useful research on the role and impact of networks in international criminal law - networks that have the potential to help strengthen domestic justice systems.

While international and hybrid courts can and should do more to contribute to justice on the ground in the years ahead, we must also be realistic about the many challenges and limitations they face in demonstrating fair justice and in capacitybuilding. For one thing, international and hybrid trials inevitably achieve only partial and imperfect justice. These tribunals can only focus on a limited number of potential defendants and their jurisdiction is restricted (often for political reasons) to limited time-frames that may only be a snap-shot of a larger conflict. The resulting trials often leave a 'justice gap' that can undermine their credibility among local audiences. Moreover, whether higher-ups or lower-level perpetrators are tried, criminal prosecutions are only partial responses to the devastating atrocities committed, and different groups within the affected societies frequently will have sharply differing views about the fairness or adequacy of the endeavor. Trials thus will often need to be supplemented by other mechanisms of post-conflict accountability and justice, such as truth and reconciliation commissions, which can provide a fuller account of a conflict and its causes, offer a greater opportunity for direct participation by victims, and recommend crucial reforms.

In terms of resources, international and hybrid trials are expensive and often compete for international funding and attention with struggling domestic justice systems. If national governments feel their domestic needs are shortchanged, this can create tensions and resentments, as in Rwanda. In fact, the gap between the resources of international or hybrid courts and those of many post-conflict justice systems is generally so enormous that they seem like completely separate and unrelated worlds. The dilapidated, sweltering courtrooms, limited legal resources, poorly paid judges, and minimal administrative support or supplies in many domestic systems stand in stark contrast to the comfortable, well-stocked, air conditioned offices, computers, ample administrative staff and other resources of the international and hybrid tribunals. But these challenges argue all the more for thinking systematically and creatively from the start about how these tribunals can advance their fundamental goal of justice through fair trials while also contributing, concretely and more substantially, to justice on the ground.

\section{Elements of a Domestic Impact Strategy}

How exactly can international and hybrid criminal courts do better to advance justice on the ground in the years ahead? By adopting a domestic impact strategy that includes three key elements, these tribunals could contribute more substantially to 
building public confidence about fair justice and to strengthening struggling domestic justice systems in societies recovering from atrocities. These three components include:

1. Understand the local terrain more deeply and fully;

2. Think systematically about the tribunal's demonstration effects and be creative about outreach; and

3. Be proactive about capacity-building and look for synergies.

Each of these elements presents conceptual and practical challenges that warrant elaboration.

\section{U nderstanding the local terrain}

First, understanding the local terrain deeply and fully is crucial to any strategy for advancing justice on the ground. Each conflict or post-conflict situation will be unique in ways that profoundly shape the possibilities for advancing justice. Countries' circumstances vary widely in crucial respects, including the condition of the domestic justice system, public attitudes and expectations about post-conflict accountability, the degree of tension among different groups or factions, the commitment (or lack thereof) of domestic leaders to accountability for atrocities, the prospects for supplementing trials with mechanisms such as truth and reconciliation commissions, reparations, and memorials, and in many other ways. Whether holding domestic or hybrid atrocity trials within the affected country is realistic at all or whether, instead, only international proceedings outside the country offer prospects for fair justice will also differ significantly across countries recovering from atrocities. All of these circumstances, especially whether domestic justice systems enjoy any degree of local legitimacy (or instead are deeply discredited) and the goals and hopes of the domestic population who endured the atrocities and must now chart a new future - will be enormously significant both in shaping the concrete possibilities for post-conflict criminal justice and in influencing public attitudes and confidence in those efforts.

In light of these challenges, international and hybrid tribunals should each have professional staff whose full-time job is to focus specifically on understanding the concerns and expectations of the local population and the needs of the domestic justice system. This team of people should be multi-disciplinary, including not only legal experts, but also country experts and anthropologists, who can work together with local leaders and civil society groups to understand the possibilities for constructive domestic outreach and capacity-building as part of a tribunal's work. To be sure, most of the people working at international or hybrid courts as prosecutors, judges, defense counsel, administrators, investigators, and so forth 
- will concentrate, as they should, on the tribunals' central responsibility of bringing to justice in fair trials those accused of atrocity crimes. As a result, they may regard questions about the domestic impact of the tribunal's work in the affected country (in terms of public perceptions about the court's work or domestic capacity-building) as not their responsibility or, at best, as an add-on to their already busy jobs. But this is precisely why having dedicated staff with specific, full-time responsibility for outreach and for capacity-building is so important. Outreach should be included explicitly in the mandate of international and hybrid tribunals, and resources for outreach - and for targeted capacity-building - should be included in their budget.

\section{D emonstration effects and outreach}

Criminal atrocity trials inevitably convey messages about justice to the multiple audiences who are aware of their work. These messages, or demonstration effects, can either build or undermine public confidence in fair justice.

Ideally, international and hybrid criminal trials (and domestic trials as well) should convey three crucial messages about justice and the rule of law. First, by holding individual perpetrators accountable for their actions, these trials demonstrate that certain conduct is out of bounds: that no matter what your cause or grievance, genocide, crimes against humanity, and war crimes are unacceptable and universally condemned. Second, atrocity trials affirm that impunity for these crimes is being punctured - that even if accountability is not perfect, increasingly it is possible, and perpetrators cannot presume on impunity. Third, trials for atrocity crimes aim to demonstrate and to reassure people that justice can be fair - both procedurally in terms of due process and, substantively, in terms of evenhanded treatment of comparable actions regardless of who committed them.

Why are these demonstration effects of atrocity trials important to justice on the ground in post-conflict societies? For very tangible reasons: Fair and credible trials bringing atrocity perpetrators to justice can begin to chip away at deep public pessimism about the possibility of meaningful justice and accountability. Most tangibly and directly, by removing perpetrators of atrocities from positions in which they can control and abuse others, criminal trials can begin to reassure the population that old patterns of almost total impunity and exploitation are no longer tolerable. Barring known perpetrators from again committing atrocities and delegitimizing them in the eyes of the public can at least begin to break patterns of rule by fear and to build public confidence that justice can be fair. When a notorious leader like Charles Taylor of Liberia is on trial for egregious crimes, for example, he is disempowered and sidelined - and his ability to wreak havoc and fear in West Africa is diminished. Demonstrating through fair trials that even those with political and economic power no longer enjoy impunity can help both to 
reduce impunity as a source of grievance and to give citizens legitimate reason to expect (and to demand) better accountability and fairer justice processes in the future, as part of a gradual step by step process of turning the corner on the past.

Of course, criminal trials can also send very mixed, contested, and imperfect messages about justice, as noted earlier. If criminal trials are widely viewed as biased, or if big fish go free while lesser offenders are held accountable - or alternatively, if direct perpetrators face no justice or accountability of any kind - those proceedings may have negative, counterproductive demonstration effects. They may send a message that justice is not fair, that previous patterns of impunity are continuing, and that deep-seated grievances will not be addressed. The complete failure to pursue accountability at all can send a similar message, contributing to a continuing public distrust of justice institutions.

In short, we cannot simply assume that positive demonstration effects will inevitably flow from holding international or hybrid trials. On the contrary, particularly given the imperfect and limited nature of international justice and the enormous challenges in achieving meaningful accountability for severe atrocities, the tribunals must work harder to engage local populations who will often be deeply skeptical of justice institutions based on bitter domestic experience. Thoughtful efforts to understand and grapple with the criticisms of skeptical domestic audiences will be essential if tribunals hope to build rather than undermine public confidence in fair justice. What is needed is meaningful outreach that grapples honestly with these challenges and difficulties, not sugar-coated press releases.

A valuable example of constructive outreach is the work of Sierra Leone's Special Court. In community town hall meetings and focused workshops all across the country, a dynamic, young team of Sierra Leonean outreach officers has engaged the population in remarkably forthright discussions about the meaning and the challenges of post-conflict justice - outreach that aims 'to promote understanding of the Special Court and respect for human rights and the rule of law in Sierra Leone.' These wide-ranging discussions led by the outreach officers have not been easy, particularly because many Sierra Leoneans deeply resent the fact that direct perpetrators of brutal atrocities, who may live right next door, are not being prosecuted. The Special Court's outreach staff has had to work hard to explain why the court is prosecuting those at the highest level as 'most responsible' rather than lower-level perpetrators, about why the Civilian Defense Forces who defended the nation are also bound by international humanitarian law, and about what procedurally fair justice looks like. A prosecution and defense before an impartial tribunal is an important concept to convey to a population deeply skeptical of the fairness of justice systems and inclined, from bitter experience, to worry that people are simply 'on the take'. But for all these challenges (and many others), this substantial outreach program has been vital in involving the Sierra Leonean people in the work of the court and in addressing their questions about 
justice and accountability. It stands in marked contrast to the lack of systematic outreach - or belated outreach - in many other post-conflict contexts.

There is no doubt that Sierra Leone's outreach efforts are having an impact in building public awareness of the Special Court's important work. In a society where travel to rural areas is difficult and access to media is limited, the outreach staff has managed - creatively and thoughtfully - to engage the population on critically important issues of justice and accountability. Survey research indicates that significant majorities are aware of the court and generally view its work positively, but other studies offer a more mixed and critical account of the outreach program. ${ }^{2}$ Additional research clearly is needed to assess the longer term impact of these outreach efforts, particularly in light of the vast domestic needs that continue to plague Sierra Leone.

Scholars and practitioners alike can help refine our understanding of the impact on the ground of different post-conflict accountability processes. We are beginning to see more empirical work, such as the studies in East Timor of the community-based reconciliation process and the perceptions of those who participated. ${ }^{3}$ Further scholarly work examining the impact of criminal atrocity trials (and other accountability mechanisms) on public understandings and confidence about justice in affected post-conflict countries could be especially useful in future efforts to develop more meaningful and effective outreach programs. Also, practitioners who have led creative outreach programs such as Sierra Leone's can offer valuable insights to those developing similar initiatives in other settings. Designing outreach programs that respond appropriately and creatively to local circumstances, and that use media and the arts in culturally resonant ways, should be an important priority in decades ahead. ${ }^{4}$

\section{Domestic Capacity-Building}

Advancing justice on the ground is not only about demonstrating that atrocity crimes are out of bounds, that impunity is being punctured, and that justice can be fair. Justice on the ground also depends on something very concrete: namely, tan-

${ }^{2}$ For research assessing the Special Court's outreach program, see Memunatu Baby Pratt, N ation-wide survey on public perceptions of the Special C ourt for Sierra L eone, 2007; Tom Perriello \& Marieke Wierda, The Spedial C ourt for Sierra $L$ eone U nder Scrutiny, International Center for Transitional Justice 36-40, March 2006; Rachel Kerr \& Jessica Lincoln, The Spedal C ourt for Sierra L eone: 0 utreach, L egacy and I mpact, War Crimes Research Group, Department of War Studies, King's College London, Draft Interim Report, July 2007.

${ }^{3}$ See Spencer Zifcak, R estorative Justice in $E$ ast Timor: A $n E$ valuation of the Community R econciliation Process of the C A V R, The Asia Foundation, 2004; Piers Pigou, The C ommunity R econciliation P rocess of the Commission for Reception, Truth, and Reconciliation, UNDP, April 2004.

${ }^{4}$ For an innovative example of radio-based outreach, see the work of Interactive Radio for Justice at http://www.irfj.org (accessed 28 November 2008) 
gible capacity-building to help strengthen struggling domestic justice systems. This is important because in many post-conflict societies, justice systems are often decimated, minimally functional, or dominated and controlled by factions for their own purposes. In such circumstances, building justice institutions worthy of public trust and confidence can be an enormously difficult and long-term process. Yet if international and hybrid courts aim to have any lasting impact in advancing justice on the ground, they should give greater attention to how they can assist domestic capacity-building in two crucial ways.

First, these courts can make - and encourage - meaningful and direct contributions to improving the domestic justice systems in the societies affected by their work. This can be called the supply side of justice on the ground. International and hybrid criminal tribunals typically enjoy a degree of international support that domestic, post-conflict justice systems can only dream of. These international resources understandably are focused on the challenging task of prosecuting perpetrators of atrocities in fair trials that meet international standards of justice. But there are opportunities for synergies - that is, for international and hybrid tribunals to contribute concretely to domestic legal capacity while doing their own important work to advance justice. In Sierra Leone, for example, the Special Court has worked with domestic police investigators, building their skills in witness management and protection and in other areas that will remain long after the Special Court has finished its work. In East Timor, domestic judges and prosecutors who gained valuable experience working on atrocity prosecutions and trials are continuing to use those skills in the domestic justice system. In Rwanda, the ICTR outreach program, despite a slow start, is placing computers at courthouses in different parts of the country, where they can be used not only by citizens interested in learning more about the ICTR but also by domestic judges doing legal research.

The possibilities for such synergies will vary, of course, depending on the particular post-conflict situation. If a country is willing to conduct domestic atrocity trials but is not fully able to do so credibly, for example, international assistance may help improve domestic capacity to hold fair trials - whether that support comes from transnational assistance networks, from the International Criminal Court, or in a combination of ways. ${ }^{5}$ If an international trial before the ICC in

\footnotetext{
${ }^{5}$ For discussion of different modes of international assistance to domestic trials, see the contribution to this issue of this journal by Mark S. Ellis, 'International Justice and the Rule of Law: Strengthening the ICC through Domestic Prosecutions'. See also Elena Baylis, 'Reassessing the Role of International Criminal Law: Rebuilding National Courts through Transnational Networks', 50 B oston C ollege L aw R eview (forthcoming); William Burke-White, 'Proactive Complementarity: The International Criminal Court and National Courts in the Rome System of Justice', $49 \mathrm{H}$ arvard I nternational L aw Journal 53 (2008); Jenia Iontcheva Turner, 'Transnational Networks and International Criminal Justice', 105 M ichigan L aw R eview 985 (2007).
} 
The Hague is necessary because a country is 'unable or unwilling' genuinely to prosecute, there may still be opportunities to contribute to domestic capacitybuilding through, for instance, workshops, discussions, and outreach (including via radio) aimed at domestic jurists, civil society leaders, and the general population. Hybrid courts located in the country that survived the atrocities may be most able to directly build domestic capacity by increasing the skills and experience of local legal professionals involved in the court's work - as judges, prosecutors, defense counsel, administrators, and investigators - at least if the national participants ultimately remain in the country to contribute to the domestic system. Hybrids can have additional impacts on the domestic system as well - for instance, by offering educational workshops for national judges and lawyers, training of investigators in witness protection, and so forth. Even in the absence of a formal hybrid arrangement, transnational networks of experts can directly assist and support domestic atrocity trials in ways that may help to build domestic capacity for fair justice. Whatever particular form this international assistance takes, those involved should look for synergies that will help strengthen domestic capacity for justice on the ground in enduring ways.

A second kind of domestic capacity-building is also crucially important, and that is empowering civil society - individuals and groups - to insist upon justice and accountability from domestic legal and political institutions. We can call this the demand side of justice on the ground. Building the rule of law is as much about strengthening public demand and confidence in justice as it is about building better legal institutions. If the public has little confidence or belief in a developing justice system, they are unlikely to turn to it to resolve disputes or to give any degree of loyalty to the ongoing project of building the rule of law.

Holding fair criminal trials of those who commit atrocities places the issue of individual legal accountability squarely on the national agenda. These proceedings can be a focal point for networks of local and international non-governmental organizations who advocate for fair justice and accountability under the law. Hybrid and international courts can help empower and build capacity among civil society organizations working on issues of justice and accountability by convening a regular forum to engage with these groups, by offering workshops to local schools and organizations, and by reaching out to populations that might otherwise have limited access to justice or political power.

Such outreach and capacity-building aimed directly at civil society can strengthen the long-term impact of international and hybrid tribunals. In East Timor, for example, international support helped build the Judicial System Monitoring Programme, an NGO that monitored proceedings before East Timor's hybrid war crimes tribunal and before its truth and reconciliation commission, and that continues to play a valuable role by evaluating the national justice system, provid- 
ing information to the wider public, and recommending reforms in the country's legal and political system. In Sierra Leone, the hybrid tribunal established the Special Court Interactive Forum, a gathering of local and international NGOs that focus primarily on the work of the court and how it can be improved, but that also network on related accountability and human rights issues. The Special Court's outreach office also helped create 'Accountability Now Clubs' across the country - clubs of university students that discuss issues of accountability, justice, human rights, and good governance in Sierra Leone, and also visit secondary and elementary schools to address these issues. Such demand-side capacity-building should also be a priority when international assistance is provided directly to support domestic criminal atrocity trials. In short, international and hybrid tribunals - and international assistance networks - can contribute significantly to justice on the ground by helping to educate and empower citizens and civil society organizations on crucial issues of legal accountability and human rights.

\section{Conclusion}

Atrocities cast a long shadow in societies that have endured the pain. Criminal trials alone, even with ambitious outreach programs, are - at best - only part of what is needed to grapple with past atrocities. Those of us involved in international criminal justice, whether as scholars or practitioners, need to be more humble about the ability of criminal trials to ever adequately address the wounds and needs of those who have suffered genocide, war crimes, or crimes against humanity. At the same time, we also need to be bolder in understanding that it is possible to hold fair trials - to do justice in individual cases - while also contributing more tangibly to justice on the ground in post-conflict societies through sensitive outreach to local communities and through capacity-building aimed at both domestic justice systems and civil society. Scholars can contribute to justice on the ground by doing valuable empirical research on the domestic impacts of international and hybrid courts and of other accountability mechanisms. Practitioners can help by thinking more systematically and creatively about how international and hybrid courts can advance their fundamental goal of justice through fair trials while also contributing more significantly to justice on the ground. Governments and organizations can help by providing explicit funding and support for outreach and capacity-building so it is not simply cobbled together on a shoestring. If we all give more attention to the complex needs, struggles, and hopes of the people and countries recovering from atrocities, we could make genuine progress in advancing justice on the ground in the challenging years ahead. 